\title{
Risk factors associated with mammary tumors in female dogs ${ }^{1}$
}

\author{
Thaisa R. Santos ${ }^{2 *}$ (D), Jacqueline R. Castro ${ }^{3}$, Júlio C. Andrade ${ }^{3}$, Ana C.R. Silva ${ }^{3}$, \\ Gustavo M.F. Silva ${ }^{2}$, Fernando A. Ferreira ${ }^{2}$, Selwyn A. Headley ${ }^{4}$ and João Paulo E. Saut ${ }^{2}$
}

\begin{abstract}
Santos T.R., Castro J.R., Andrade J.C., Silva A.C.R., Silva G.M.F., Ferreira F.A., Headley S.A. \& Saut J.P.E. 2020. Risk factors associated with mammary tumors in female dogs. Pesquisa Veterinária Brasileira 40(6):466-473. Faculdade de Medicina Veterinária, Universidade Federal de Uberlândia, Campus Umuarama, Avenida Pará 1720, Bloco 2T, Bairro Umuarama, Uberlândia, MG 38400-902, Brazil. E-mail: thaisareis.vetufu@gmail.com

Mammary tumors in female dogs are the most frequent and corresponds to half of the canine tumors. The objectives of this study were to determine the risk factors associated with the occurrence of mammary tumors in female dogs and to evaluate the macroscopic characteristics of these neoformations, using 386 dogs from the "Outubro Rosa Pets" events done within the cities of Uberlândia and Patos de Minas, Minas Gerais State, Brazil, in 2015 $(\mathrm{n}=194), 2016(\mathrm{n}=105)$ and $2017(\mathrm{n}=87)$. For the determination of risk factors, the binary logistic regression test $(\mathrm{P}<0.05)$ was performed. The occurrence of mammary tumors was $23.6 \%(91 / 386)$. The significant risk factors identified were increased age $(\mathrm{P}<0.001)$, overweight $(\mathrm{P}=0.048)$ and non-castration $(\mathrm{P}<0.001)$ with a chance of, respectively, $1.6,2.3$ and 9.3 times for the development of mammary tumors. In dogs with mammary tumors $(n=91)$, 153 lesions were present, of which 39 female dogs had two or more lesions (42.8\%). Most of the lesions were at the caudal abdominal (M4) and inguinal (M5) mammary glands $(60.13 \%$, $92 / 153)$. Relative to the size of the lesions, it was observed that in $78 \%$ of the female dogs the lesions were determined asT1 $(<3 \mathrm{~cm}), 16.5 \%$ were T2 $(3-5 \mathrm{~cm})$ and $5.5 \% \mathrm{~T} 3(>5 \mathrm{~cm})$. At least $15.4 \%$ (14/91) of the dogs had one of the regional lymph nodes increased. In conclusion, the occurrence of mammary tumors in the evaluated population was $23.6 \%$ and that age, overweight and non-realization of ovariohysterectomy are risk factors associated with the development of mammary tumors.
\end{abstract}

INDEX TERMS: Mammary tumors, female dogs, bitches, Minas Gerais, Brazil, ovariohysterectomy, overweight, prevention, risk factors, dogs.

RESUMO.- [Fatores de risco para tumores mamários em cadelas de Uberlândia e Patos de Minas, Minas Gerais.] Em cadelas os tumores mamários são os mais frequentes e correspondem a aproximadamente metade dos tumores em cães. Este estudo teve os objetivos de determinar os fatores de risco envolvidos na ocorrência de tumores mamários em

\footnotetext{
${ }^{1}$ Received on July 10, 2019.

Accepted for publication on July 27, 2019.

Doctoral Research with support from CAPES.

${ }^{2}$ Faculdade de Medicina Veterinária, Universidade Federal de Uberlândia (UFU), Campus Umuarama, Avenida Pará 1720, Bloco 2T, Bairro Umuarama, Uberlândia, MG 38400-902, Brazil. *Corresponding author: thaisareis.vetufu@gmail.com

${ }^{3}$ Centro Universitário de Patos de Minas (Unipam), Rua Major Gote 808, Caiçaras, Patos de Minas, MG 38700-207, Brazil.

${ }^{4}$ Laboratório de Patologia Animal, Universidade Estatual de Londrina (UEL), Rodovia Celso Garcia Cid PR-445 Km 380, Campus Universitário, Cx. Postal 10.011, Londrina, PR 86057-970, Brazil.
}

cadelas e avaliar as características macroscópicas destas neoformações, utilizando 386 cadelas do evento "Outubro Rosa Pets" nos municípios de Uberlândia e Patos de Minas, Minas Gerais, Brasil, em 2015 ( $n=194), 2016$ (n=105) e 2017 $(\mathrm{n}=87)$. Para a determinação dos fatores de risco utilizou-se o teste de Regressão logística binária $(\mathrm{P}<0,05)$. A ocorrência de tumores mamários foi de 23,6\% (91/386). Os fatores de risco significativos identificados foram aumento da idade $(\mathrm{P}<0,001)$, sobrepeso $(\mathrm{P}=0,048)$ e não-castração $(\mathrm{P}<0,001)$ com a chance de, respectivamente, 1,6, 2,3 e 9,3 vezes de desenvolvimento de tumores mamários. Nas cadelas com tumores mamários ( $\mathrm{n}=91)$, constatou-se a presença de 153 lesões, sendo que 39 cadelas apresentaram duas ou mais lesões $(42,8 \%)$. A maioria das lesões localizaram-se nas mamas abdominais caudais (M4) e inguinais (M5) (60,13\%; 92/153). Em relação ao tamanho das lesões, observou-se que $78 \%$ das cadelas 
eram T1 $(<3 \mathrm{~cm}), 16,5 \%$ T2 $(3-5 \mathrm{~cm})$ e $5,5 \%$ T3 $(>5 \mathrm{~cm})$. Pelo menos 15,4\% (14/91) das cadelas apresentaram um dos linfonodos regionais aumentados. Conclui-se que a ocorrência dos tumores mamários na população avaliada foi de 23,6\% e que a idade, sobrepeso e não ovariohisterectomia são fatores de risco para o desenvolvimento de tumores mamários.

TERMOS DE INDEXAÇÃO: Fatores de risco, tumores mamários, cadelas, Minas Gerais, Brasil, ovariohisterectomia, prevenção, sobrepeso, tumor de mama.

\section{INTRODUCTION}

Mammary tumors are the most frequently diagnosed in female dogs and are responsible for approximately $50 \%$ of canine tumors (Queiroga \& Lopes 2002, Kumaraguruparan et al. 2006, Cassali et al. 2014). In both veterinary and human medicine, breast cancer has resulted in numerous studies aimed at prevention and early diagnosis, mainly because this alteration is associated with elevated morbidity and mortality rates in the affected patients (Humphrey et al. 2002, Cassali et al. 2014, Pascoli et al. 2017).

Canine mammary tumors serve as appropriate and valid experimental models for the study of cancer biology in humans due to the similarity of epidemiological, clinical, biological and genetic characteristics (Silva at al. 2004, Kumaraguruparan et al. 2006). Studies have shown that obesity, age, sex, nutrition, and hormonal activities are associated with the etiology of breast cancer in dogs and women (Pérez Alenza et al. 1998, Cassali et al. 2014, Takalkar et al. 2016).

Although in female dogs, breast tumors may occur in any of the mammary glands, with the presence of multiple nodules with similar or different histological patterns are frequently described (Queiroga \& Lopes 2002, Oliveira et al. 2003, Hellmén 2005, Cassali et al. 2014). Careful physical examination of the mammary glands, assessment of regional lymph nodes, distant organ metastasis, and histopathological examination are essential factors to determine the diagnosis, prognosis, and treatment. In addition, it is recommended to define the severity of the disease by staging the patient based on tumor size (T), presence of metastases in the lymph node(N) and distant metastases (M), according to the TNM system established by the World Health Organization, WHO (Owen 1980).

In female dogs with mammary neoplasms pulmonary metastases are frequently observed, but dissemination can also occur in lymph nodes, myocardium, spleen, adrenals, bones, and the brain (Misdorp 2002, Cassali et al. 2014). Additionally, retarded diagnosis makes treatment difficult and reduces survival of affected animals (Silva et al. 2004, Cavalcanti \& Cassali 2006, Estrela-Lima et al. 2010, Toríbio et al. 2012). Alternatively, the realization of early ovariohysterectomy $(\mathrm{OSH})$, i.e., begore the third estrus cycle, positively impacts the reduction of the development of mammary neoplasms in dogs and is an important form of prevention (Sonnenschein et al. 1991, Fonseca \& Daleck 2000).

Since 1990, actions have been taken during the month of October to alert women about breast cancer prevention (INCA 2016). Recently, veterinary medicine has taken advantage of this month to promote actions to provide guidance on the prevention of breast cancer and the awareness of tutors regarding clinical signs, diagnosis and treatment, as well as collecting data relative to epidemiology and risk factors for this disease (Pascoli et al. 2017). The objective of this study was to determine the risk factors associated with the occurrence of mammary tumors in female dogs and to evaluate the macroscopic characteristics of these neoformations, using the database of the "October Rosa Pets" events maintained at cities of Uberlândia and Patos de Minas, Minas Gerais (MG), from 2015 to 2017.

\section{MATERIALS AND METHODS}

The study was done according to the ethical principles for experimentation of the Ethics Committee for Animal Use (CEUA), "Centro Universitário de Patos de Minas" (Unipam), under protocol number 50/17 and with authorization of the owners of the animals, based to the terms outlined in the consent forms that were made available and signed by all participating clients.

Study design and characterization of the study population. A retrospective cross-sectional study was done by using the evaluation and analysis of the clinical records completed during the realization of the mammary cancer prevention events in female dogs. These events took place within the cities of Uberlândia and Patos de Minas/ MG, during 2015, 2016, and 2017.

The "October Rosa Pets" campaign was conducted by undergraduate students in Veterinary Medicine, under the supervision of professors and veterinarians of the "Universidade Federal de Uberlândia" (UFU), "Centro Universitário do Triângulo" (Unitri), and the "Centro Universitário de Patos de Minas" (Unipam). The campaign was realized in a public place with free access to the population of both cities. All animals participated voluntarily in the event and were subjected to specific clinical examination of the mammary glands, as recommended by Feitosa (2014). The axillary and inguinal lymph node nodes of all dogs were palpated and evaluated for size, mobility, consistency, shape, surface regularity, and temperature. Additionally, the nipples of the mammary glands were massaged and drained to assess the possible presence of secretions (Cassali et al. 2014).

Inclusion criteria and epidemiological survey. The inclusion criteria established for the present study were female dogs of different weights and sizes, irrespective of breed and age, who voluntarily participated in the mammary cancer prevention campaign and were selected for participation (Fig.1).

The independent variables analyzed to establish possible predictors for the development of mammary tumors in dogs were: a) age (years); b) breed, classified as mixed and pure breeds; c) realization of ovariohysterectomy, OSH (no/yes); d) history of pseudo-pregnancy (no/yes); e) diet identification, being considered ration when the supply was exclusive of commercial rations and mixed when the diet consisted of homemade diet with or without commercial rations; f)

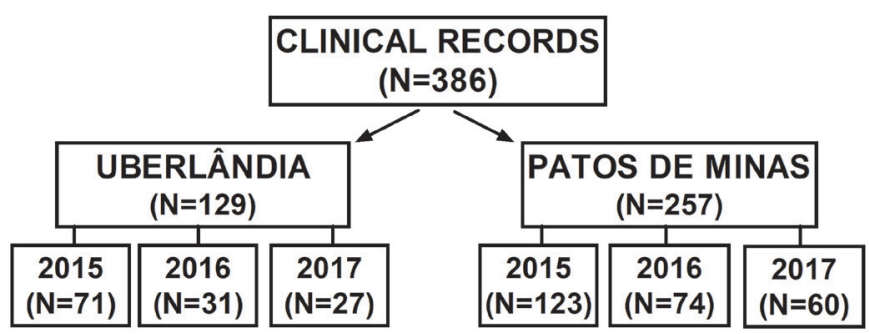

Fig.1. Flowchart of the dogs participating in the retrospective clinical study to determine risk factors and the occurrence of mammary tumors, at the "October Rosa Pets", event held in Uberlândia and Patos de Minas/MG, during 2015, 2016 and 2017. 
history of contraceptive use (no/yes); g) parturition history (no/ yes); h) overweight, evaluated based on the body condition score, being considered overweight female dogs presenting a score 4 or 5 on the scale of 1 to 5, as described (Edney \& Smith 1986).

Information relative to the clinical evaluation of the mammary chain of all animals included: presence or absence of mammary gland enlargement, tumor characteristics (size, consistency, shape, surface, adherence, and ulceration), evaluation of regional lymph nodes (axillary and inguinal), presence or absence of secretion and location of the lesion (M1 = right or left cranial thoracic mammary gland, M2 = right or left caudal thoracic mammary gland, M3 = right or left cranial abdominal mammary gland, M4 = right or left caudal abdominal mammary gland and M5 = right or left inguinal mammary gland) (Cassali et al. 2014). To determine the size of the lesion, a pachymeter in millimetres, using the TNM clinical staging system ( $\mathrm{T}$ = tumor, $\mathrm{N}$ = lymph node, $\mathrm{M}$ = metastasis) was used as described (Owen 1980, Cassali et al. 2014). The largest length of each lesion was measured $(\mathrm{cm})$, after which the lesions were classified as T1 (when the tumor was less than $3 \mathrm{~cm}$ in length), T2 (3 to $5 \mathrm{~cm}$ ) and T3 $(>5 \mathrm{~cm})$. Only the largest tumor was evaluated in dogs with more than one mammary tumor.

Statistical analysis. The statistical analysis was done by using the binary logistic regression model, via the IBM SPSS 21.0 Statistical Program (IBM Corp., Armonk/NY, USA). To achieve this, the dependent variable (binary) was determined as the results (yes/no) for the presence of mammary tumors at during physical examination, and the following were considered as independent variables: a) quantitative: IN1-age (years); b) qualitative: IN2- breed (0-SRD/1purebred), IN3- diet (0-ration/1-mixed), IN4- contraceptive usage (0-no/1-yes), IN5- ovariohysterectomy (0-yes/1-no), IN6- pseudopregnancy (0-no/1-yes), IN7- parturition history (0-yes/1-no), IN8- overweight (0-no/1-yes). The descriptive statistical analysis of the data was presented as the absolute and relative frequency of each of the independent variables $(n=8)$ relative to the dependent variable (mammary tumor).
Chi-square and Fisher's exact tests were used to determine if there was any difference in the frequency of animals with mammary tumors between the evaluation period and the onset of OSH, respectively. Continuous variables were submitted to the Shapiro-Wilk test as normal distribution $(\mathrm{P}>0.05)$. Variables between the three years of the study were analyzed by the Mann Whitney test (nonparametric variables) and ANOVA (parametric variables). All análises were considered significant if $\mathrm{p}<0.05$ and tendência if $0.05<\mathrm{p}<0.1$.

\section{RESULTS}

A total of 386 female dogs from the "October Rosa Pets" event was examined in the cities of Uberlândia and Patos de Minas/MG, during $2015(n=194), 2016(n=105)$, and $2017(n=87)$. The epidemiological data of the evaluated population, based on the years of study, are provided in Table 1. Mammary tumors occurred in $23.6 \%(91 / 386)$ of the population evaluated. There was no difference $(\mathrm{P}=0.346)$ between the number of animals affected by mammary tumors lesions between 2015 (26.3\%), 2016 (22.8\%), and 2017 (18.4\%).

When the number of dogs $(n=91)$ with mammary tumors was evaluated, 153 neoplastic growth were identified, with $42.8 \%$ (39/91) of dogs presented two or more mammary tumors. Most $(60.1 \%, 92 / 153)$ of the neoplastic growths were located at the caudal (M4) and inguinal (M5) abdominal mammary glands. When the size of the mammary tumors was evaluated, in 78.0\% (71/91) of the dogs evaluated contained neoplastic growths at T1, 16.5\% (15/91) were located at T2, and 5.5\% (5/91) at T3 (Fig.2). At least 15.4\% (14/91) of the dogs evaluated had one of the regional lymph nodes enlarged on palpation.

From the total of 386 dogs used in this study, 96.4\% $(n=372)$ were eligible for inclusion in the binary logistic regression, since the clinical form of these animals contained all data of the independent variables, while dogs $(n=14)$ with at least one of the missing information were eliminated. Eight

Table 1. Epidemiological data of female dogs treated at "October Rosa Pets" and presence of mammary gland tumors, according to the year of study, in the cities of Uberlândia and Patos de Minas/MG, during 2015, 2016 and 2017

\begin{tabular}{|c|c|c|c|}
\hline & \multicolumn{3}{|c|}{ Evaluation year } \\
\hline & $2015(n=194)$ & $2016(n=105)$ & $2017(n=87)$ \\
\hline No. of breeds & 20 & 21 & 19 \\
\hline Predominant breeds & $\begin{array}{l}\text { Mixed breed (45.9\%); } \\
\text { Dachshund (11.8\%); } \\
\text { Shitzu }(8.8 \%) ; \\
\text { Poodle }(8.2 \%) ; \\
\text { Yorkshire }(4.6 \%)\end{array}$ & $\begin{array}{l}\text { Mixed breed (43.8\%); } \\
\text { Poodle (9.5\%); } \\
\text { Shitzu (8.6\%); } \\
\text { Border Collie }(6.7 \%) ; \\
\text { Pinscher }(4.8 \%) ; \\
\text { Dachshund }(4.8 \%)\end{array}$ & $\begin{array}{l}\text { Mixed Breed (45.9\%); } \\
\text { Shitzu }(10.3 \%) ; \\
\text { Pinscher }(8.0 \%) ; \\
\text { Yorkshire }(4.6 \%) ; \\
\text { Border Collie }(4.6 \%)\end{array}$ \\
\hline $\begin{array}{l}\text { Predominant breeds in female } \\
\text { dogs with mammary cancer }\end{array}$ & $\begin{array}{l}\text { Mixed Breed (49.9\%); Poodle } \\
(17.6 \%) ; \\
\text { Pinscher (13.7\%); } \\
\text { Basset Hound (5.9\%); Shitzu } \\
(3.9 \%) ; \\
\text { Yorkshire }(3.9 \%)\end{array}$ & $\begin{array}{l}\text { Mixed Breed (54.2\%); } \\
\text { Poodle (20.8\%); } \\
\text { Dachshund (8.3\%); } \\
\text { Boxer (4.2\%), } \\
\text { Basset Hound (4.2\%), } \\
\text { Pinscher }(4.2 \%) ; \\
\text { Pitbull }(4.2 \%)\end{array}$ & $\begin{array}{l}\text { Mixed Breed (81.2\%); } \\
\text { Poodle }(6.2 \%), \\
\text { Chow Chow }(6.2 \%) ; \\
\text { Cocker Spaniel }(6.2 \%)\end{array}$ \\
\hline General age * & $4 a(P 25 \%-75 \%=1.6-7)$ & $4 \mathrm{a}(\mathrm{P} 25 \%-75 \%=1.5-8)$ & $3.5 \mathrm{a}(\mathrm{P} 25 \%-75 \%=1-7)$ \\
\hline Age - dogs with mammary tumors & $8.2 \mathrm{a}( \pm 3.24)$ & $8.5 a( \pm 2.48)$ & $8.79 a( \pm 4.53)$ \\
\hline$\%$ Mammary tumors & $26.3 \%(56 / 194)$ & $22.8 \%(21 / 105)$ & $18.4 \%(19 / 87)$ \\
\hline
\end{tabular}

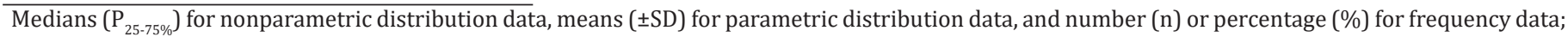
${ }^{a}$ similar superscript letters on the same line indicate no statistical difference $(\mathrm{P}>0.05)$. 
possible predictors or risk factors for the development of mammary tumors in female dogs were evaluated; the relative and absolute frequencies are given in Table 2.

The model containing all eight independent variables was significant $\left[\chi 2\right.$ (G.L.8) = 163.134; $\mathrm{p}<0.001 ; \mathrm{R} 2_{\text {Nagelkerke }}=0.537$ ]; the Hosmer and Lemeshow tests were equal to $\chi 2$ (G.L.8) $=7.011$ $(\mathrm{P}=0.535)$. With this model three predictors or significant risk factors $(\mathrm{P}<0.05)$ for the development of mammary tumors in female dogs were identified (Table 3). The factors increase in age (years), non-realization of $\mathrm{OSH}$, and overweight (score 4 and 5) were considered predictors or significant risk factors for the development of mammary tumors.

There was a tendency for the frequency $(27.6 \%, 13 / 47)$ of mammary tumors to increase in dogs that were submitted to OSH after the third estrus cycle $(\mathrm{P}=0.0848$ - Fisher's Exact
Test), when compared with dogs submitted to OSH before the third estrus cycle $(9.4 \%, 3 / 32)$.

\section{DISCUSSION}

This study reinforced the importance of mammary tumors in the canine population, using information from derived from the database of the prevention campaigns of mammary gland tumor in female dogs from the cities of Uberlândia and Patos de Minas, Minas Gerais, from 2015 to 2017. Although the animals participated voluntarily via adhesion of their tutors, this exploratory observational and case-dependent study, the relative frequency mammary tumors (23.6\%) herein identified, was comparatively more elevated than $15.3 \%$ (17/111) described in survey done during a similar
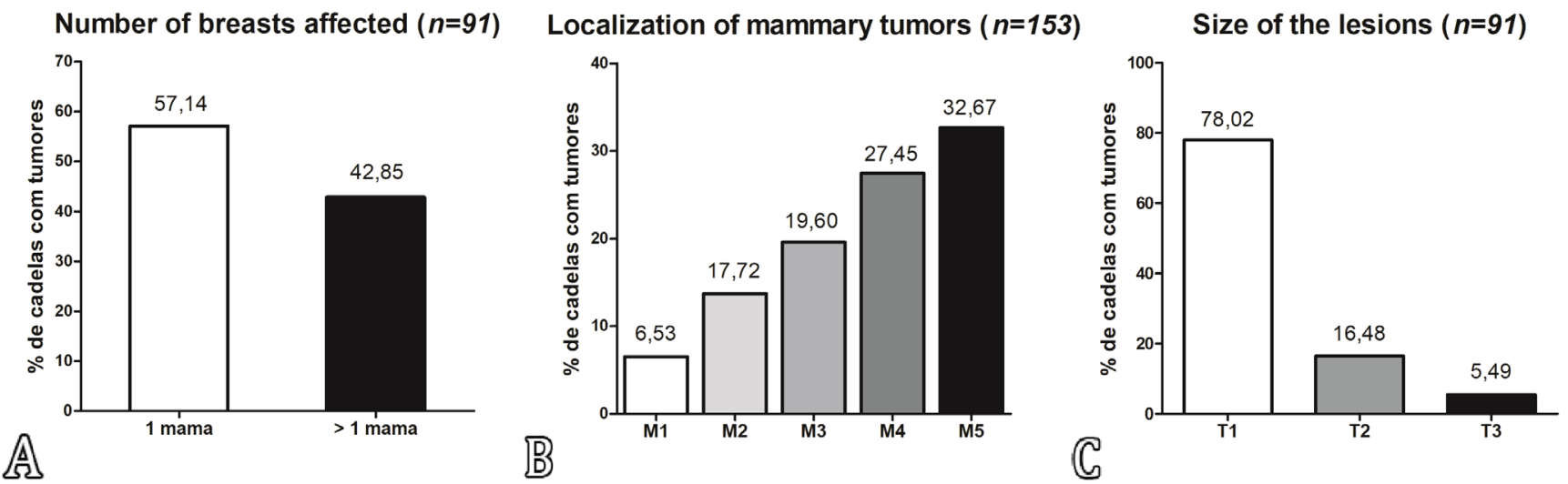

Fig.2. Female dogs with mammary tumors evaluated in the "October Rosa Pets" event, held in the city of Uberlândia and Patos de Minas/ MG, during 2015, 2016 and 2017. (A) Number of breasts affected. (B) Localization of mammary tumors (M1 = right or left cranial thoracic mammary gland, M2 = right or left caudal thoracic mammary gland, M3 = right or left cranial abdominal mammary gland, M4 = right or left caudal abdominal mammary gland, and M5 = right or left inguinal mammary gland). (C) Size of the lesions (T1 = tumors $<3 \mathrm{~cm}$ in diameter, $\mathrm{T} 2=3-5 \mathrm{~cm}$, and $\mathrm{T} 3=>5 \mathrm{~cm})$.

Table 2. Distribution of the relative and absolute frequencies of possible predictors or qualitative risk factors associated with the development of mammary neoplasms in female dogs during "October Rosa Pets" events in the cities of Uberlândia and Patos de Minas/MG, during 2015, 2016 and 2017

\begin{tabular}{|c|c|c|c|c|}
\hline \multirow{2}{*}{\multicolumn{2}{|c|}{ Independent variable - IV (qualitative) }} & \multicolumn{3}{|c|}{ Female dogs } \\
\hline & & \multirow{2}{*}{$\begin{array}{c}\text { Total n(\%) } \\
169(45.4 \%)\end{array}$} & \multirow{2}{*}{$\begin{array}{c}\text { Tumors (n) } \\
49\end{array}$} & \multirow{2}{*}{$\begin{array}{c}\text { Frequency (\%) } \\
28.9 \%\end{array}$} \\
\hline IV 2 - Tyme of hreed & Mixed breed $(0)$ & & & \\
\hline IV 2 - Type of breed & Pure breeds $(1)^{*}$ & $203(54.6 \%)$ & 37 & $18.2 \%$ \\
\hline IV3 - Diet & Ration (0) & $255(68.5 \%)$ & 47 & $18.4 \%$ \\
\hline IV4 - Contraceptive use & Yes (1) & $26(7 \%)$ & 14 & $53.8 \%$ \\
\hline IV 5 - Ovariohysterectomy & No (1) & $293(78.8 \%)$ & 70 & $23.9 \%$ \\
\hline \multirow{2}{*}{ IV 6 - History of false pregnancy } & Yes (1) & $101(27.2 \%)$ & 41 & $40.6 \%$ \\
\hline & No $(0)$ & $271(72.8 \%)$ & 45 & $16.6 \%$ \\
\hline \multirow{2}{*}{ IV 7 - History of parturition } & Yes $(0)$ & $100(26.9 \%)$ & 39 & $39 \%$ \\
\hline & No (1) & $272(73.1 \%)$ & 47 & $17.3 \%$ \\
\hline
\end{tabular}

The variable IV 1 = age did not enter because it is an independent quantitative variable; * (1) identifies the reference category used for the Binary Logistic Regression Test $(\mathrm{P}<0.05)$. 
event in the city of Blumenau, Santa Catarina, in 2014 (Pascoli et al. 2017). Interestingly, the results herein described are similar to those identified in a population of 1,359 female dogs attended at the "Hospital Veterinário" of the "Universidade Federal da Bahia", where a prevalence of $24.7 \%$ was reported (Toríbio et al. 2012).

The prevalence of mammary tumors is usually based on studies derived from the general population of animals treated at Veterinary Hospitals or a specific population of dogs with cancer (De Nardi et al. 2002, Oliveira et al. 2003, Filho et al. 2010, Toríbio et al. 2012). However, studies describing the prevalence of mammary tumors in a canine population from a given region were not located when major databases were accessed, as is well established for breast tumors in humans. Consequently, the occurrence described in this paper highlights the importance of this pathology in the female canine population in the cities of Uberlândia and Patos de Minas and suggests that additional studies should be done to fill the reduced number of epidemiological studies that determined the actual prevalence of mammary tumors in the canine populations and not just in canine hospitals.

Among the risk factors evaluated, we must highlight importance of the age predictor, which increases the risk of breast tumor by 1.625 times annually; these results are in accordance with other studies that indicated a greater predisposition of elderly female dogs for the development of neoformations of the mammary gland (Rutteman et al. 2001, Egenvall et al. 2005, Stratmann et al. 2008, Sorenmo et al. 2009).

In addition to age, spaying was identified as a protective factor for the occurrence of mammary tumors, since uncastrated female dogs were 9,344 times more likely to have breast tumors compared with dogs submitted to OSH surgery. It was reported that early castration positively influences the reduction in the occurrence of mammary tumors pathology, with $99.5 \%$ reduction if performed prior to the first estrous cycle (Fonseca \& Daleck 2000). However, there is no consensus on this marked reduction, since several authors (Kristiansen et al. 2016, Pascoli et al. 2017) did not identify a similar relationship. In the present study, it was observed that within the group of castrated female dogs, there was a tendency for the reduction of mammary tumors in those castrated before the third estrous cycle (9.4\%), when compared to castrated female dogs after the third estrous (27.6\%), indicating that early castration may be more effective in reducing the risk of mammary tumors in female dogs.
Additionally, OSH done even after the third estrous cycle in association with mastectomy, is associated with the reduced recurrence of benign breast lesions, and in preventing the occurrence of uterine and ovarian diseases (Kristiansen et al. 2013). Furthermore, the realization of OSH influences the survival rate of female dogs with mammary carcinoma (Sorenmo et al. 2000). In the present study, most (78.8\%, 293/372) of the evaluated female dogs were not ovariohysterectomized, demonstrating the need for additional spaying campaigns in the canine population of the studied municipalities, considering the benefits associated with this procedure.

In this study, contraceptive usage and pseudo-gestations were not considered as risk factors for mammary carcinogenesis; similar results were described by Pascoli et al. (2017) who found no association between contraceptive use and mammary tumors, being different from the observations Fonseca \& Daleck (2000) and Silva et al. (2004). Contraceptive usage was low $(7 \%)$ in the study population herein described; reduced (11.6\%) use of contraceptive was also described in female dogs and this tendency was more prevalent (41\%) among less literate and low-income tutors (Toríbio et al. 2012).

It must be highlighted that exogenous progesterone stimulates growth hormone synthesis in the mammary gland with lobe-alveolar proliferation and consequent hyperplasia of myoepithelial and secretory elements, inducing the formation of benign or malignant nodules in young animals and may increase the number of estrogenic receptors (Silva et al. 2004). Additionally, estrogen and prolactin are involved in the growth of breast cancer (Fonseca \& Daleck 2000). Receptors for estrogen, progesterone, androgens, prolactin, and epidermal growth factor have been demonstrated in female mammary tumors, with a possible relationship between the number of these receptors and the proliferative capacity of neoplastic cells being proposed (Silva et al. 2004).

During this study, overweighed animals had an increased risk (2.331x) for the development of tumor tumors, which was not influenced by the breed of the affected dog; breed was not considered as a risk factor based on the proposed grouping (mixed breed and pure breeds). These results corroborate with the proposed association between overweight and obesity with the occurrence of mammary tumors (Pascoli et al. 2017). Moreover, obesity was observed in $26.8 \%$ of the female dogs, and $80 \%$ of these obese and breast cancer patients received homemade diet (Toríbio et al. 2012). In the present study, the number of overweighed dogs with mammary tumor was

Table 3. Risk factors associated with the development of mammary neoplasms in female dogs during "October Rosa Pets" events in the cities of Uberlândia and Patos de Minas/MG, during 2015, 2016 and 2017

\begin{tabular}{|c|c|c|c|c|}
\hline Risk factors & Coefficient & P-value & Exp (B) Odds ratio & $95 \% \mathrm{CI}$ \\
\hline Constant & -5.758 & 0.000 & 0.003 & \\
\hline IV 1 - Age & 0.486 & $0.000^{*}$ & 1.625 & $(1.448-1.824)$ \\
\hline IV 2 - Breed (1) & 0.370 & 0.284 & 1.447 & $(0.736-2.847)$ \\
\hline IV 4 - Contraceptive use (1) & 0.843 & 0.105 & 2.324 & $(0.838-6.443)$ \\
\hline IV 5 - Ovariohysterectomy (1) & 2.235 & $0.000^{*}$ & 9.344 & $(3.480-25.09)$ \\
\hline IV 8 - Overweight (>3/1-5) (1) & 0.846 & $0.048^{*}$ & 2.331 & $(1.006-5.400)$ \\
\hline
\end{tabular}

$\mathrm{CI}=$ Confidence interval; ${ }^{*}$ significant risk factor $(\mathrm{P}<0.05)$ for the development of mammary tumors in female dogs; (1) identifies the reference category used for the Binary Logistic Regression test $(\mathrm{P}<0.05)$ as described in Table 2. 
higher $(36.8 \%, 25 / 68)$ than that described by Toríbio et al. 2012. Additionally, the number of the overweighed dogs and with mammary tumor $(64 \%, 16 / 25)$ that received a mixed diet was significantly $(\mathrm{P}=0.0261)$ higher than non-obese dogs and with tumors $(37.7 \%, 23 / 61)$; these results are in accordance with the direct relationship observed between the type of food and the body condition of dogs with tumors (Toríbio et al. 2012).

Obesity in women may alter the expression of progesterone receptors, interferes with the course of the disease and may influence the survival rate of the patient (Sparano et al. 2012). Additionally, it was shown that obese women had high concentrations of oestrogen derived from transformed fatty tissue, with the transformation of androstenedione into estrone and later into oestrogen (Yoo et al. 2001). Since obesity is related to worse prognosis for breast cancer in women (Widschwendter et al. 2015, Choi et al. 2016), nutritional factors may be an important contributor towards the etiology of mammary tumors in dogs (Sonnenschein et al. 1991). According to Pérez Alenza et al. (1998), and as was demonstrated in this study, risk factors such as advanced age and obesity are associated with the development of canine mammary tumors. Furthermore, although the pathophysiological mechanisms are still poorly understood, there may be a relationship between obesity, inflammation and cancer (Argolo et al. 2015).

Relative to the size of the lesions, $78 \%$ of the dogs had smaller T1 nodules $(<3 \mathrm{~cm})$, differing from Toríbio et al. (2012), who observed a higher prevalence (36.6\%) of female dogs with stage III breast cancer; T3N0M0 $(>0.5 \mathrm{~cm}$ and no metastases in lymph nodes and distant organs). We propose that tutors from the cities studied seem concerned about the disease and joined the campaign in a positive way, showing up with their animals at an early stage of the disease.

Moreover, these results reinforce the importance of early detection of mammary tumors for a better prognosis and response to therapy, since there is a positive correlation between tumor size and malignancy, as well as the tumor size and the presence of distant metastases (Sorenmo 2003, Toríbio et al. 2012, Cassali et al. 2014).

The caudal and inguinal abdominal mammary glands were the most frequently affected (60.1\%); similar results were previously described (Cassali et al. 2014, Pascoli et al. 2017), and may be related to the larger amount of parenchyma tissue within these mammary glands and, consequently, greater hormonal stimulation (Rutteman et al. 2001).

The regional lymph nodes were enlarged in $15.4 \%$ of the dogs evaluated. It must be highlighted that axillary and inguinal lymph nodes may be affected by mammary neoplasia, and are important routes for distant metastases, which occurs in 5 to $10 \%$ of dogs during the first three years after a diagnosis was established (Bloom et al. 1962, Cassali et al. 2014). Additionally, regional lymph node metastasis is an unfavorable prognostic factor (Hellmén et al. 1993, Toríbio et al. 2012). However, it cannot be confirmed in this study that lymph node enlargement was related to metastasis, since complementary evaluations such as cytology and/or histopathology were not performed.

In this study, the number of pure breed dogs was over representative $(n=28)$, which made it difficult to evaluate each bread individually, which would have been the ideal situation. According to the division proposed in this study (mixed breed and pure breed), the breed of the affected dogs was not a risk factor for the development of mammary tumor. Although, a genetic predisposition for the development of mammary cancer in Poodles was proposed (Misdorp 2002), there may be no breed predisposition to mammary cancer (Cavalcanti \& Cassali 2006), even though in certain breeds tumors are more frequently diagnosed.

The results obtained in this study reinforce the theory that age, obesity and non-realization of OSH influence the increased risk for mammary tumors in female dogs. However, the absence of studies designed directly at the canine population of a given region to determine the occurrence of mammary tumors in dogs and to verify the real impact of these factors. In human medicine, studies to determine the risks of cancer in Brazil are relevant public health issues, and there is a continuing need for research on this topic for the development of appropriate health policies aimed at cancer control in the country (Guerra et al. 2005).

Knowing the influence of the risk factors associated with the development of mammary tumors in female dogs in a given canine population, will facilitate the establishment of adequate and well designed-based strategies to prevent and reduce the occurrence of this neoplasm.

\section{CONCLUSION}

The occurrence of mammary tumors in the evaluated population was $23.6 \%$, while age, overweight and non-realization of OSH were considered as risk factors for the development of mammary tumors in female dogs.

Acknowledgements.- The CAPES Foundation for the PhD scholarship provided to the first author (Santos T.R.). The authors thank "Liga Acadêmica de Oncologia Veterinária”, “Centro Universitário de Patos de Minas”, the "Programa de Educação Tutorial”, "Faculdade de Medicina Veterinária”, "Universidade Federal de Uberlândia", and the "Grupo de Estudos de Pequenos Animais", "Centro Universitário do Triângulo" for their commitment, participation and dedication in the realization of the Campaign "Outubro Rosa Pets".

Conflict of interest statement.- There are no conflicts of interest.

\section{REFERENCES}

Argolo D.F., Iyengar N.M. \& Hudis C.A. 2015. Obesity and cancer: concepts and challenges. Indian J. Surg. Oncol. 6(4): 390-398. <http://dx.doi.org/10.1007/ s13193-015-0483-Z> <PMid:27081257>

Bloom H.J., Richardson W.W. \& Harries E.J. 1962. Natural history of untreated breast cancer (1805-1933). Comparison of untreated and treated cases according to histological grade of malignancy. Brit. Med. J. 2(5299):213221. <http://dx.doi.org/10.1136/bmj.2.5299.213> <PMid:13870135>

Cassali G.D., Lavalle G.E., Ferreira E., Estrela-Lima A., De Nardi A.B., Ghever C., Sobral R.A., Amorim R.L., Oliveira L.O., Sueiro F.A.R., Beserra H.E.O., Bertagnolli A.C., Gamba C.O., Damasceno K.A., Campos C.B., Araujo M.R., Campos L.C., Monteiro L.N., Nunes F.C., Horta R.S., Reis D.C., Luvizotto M.C.R., Magalhães G.M., Raposo J.B., Ferreira A.M.R., Tanaka N.M., Grandi F., Ubukata R., Batschinski K., Terra E.M., Salvador R.C.L., Jark P.C., Delecrodi J.E.R., Nascimento N.A., Silva D.N., Silva L.P., Ferreira K.C.R.S., Frehse M.S., Di Santis G.W., Silva E.O., Guim T.N., Kerr B., Cintra P.P., Silva F.B.F., Leite J.S., Mello M.F.V., Ferreira M.L.G., Fukumasu H., Salgado B.S. \& Torres R. 2014. Consensus for the diagnosis, prognosis and treatment of canine mammary tumors - 2013. Braz. J. Vet. Pathol. 7(2):38-69.

Cavalcanti M.F. \& Cassali G.D. 2006. Fatores prognósticos no diagnóstico clínico e histopatológico dos tumores de mama em cadelas - revisão. Revta Clín. Vet. 61:56-63. 
Choi Y., Park S. K.., Ahn K.J., Cho H., Kim T.H., Yoon H. K. \& Lee Y.H. 2016. Being overweight or obese increases the risk of progression in triple-negative breast cancer after surgical resection. J. Korean Med. Sci. 31(6):886-891. <http://dx.doi.org/10.3346/jkms.2016.31.6.886> <PMid:27247497>

De Nardi A.B., Rodaski S., Sousa R.S., Costa T.A., Macedo T.R., Rodigheri S.M., Rios A. \& Piekarz C.H. 2002. Prevalência de neoplasias e modalidades de tratamentos em cães, atendidos no hospital veterinário da Universidade Federal do Paraná. Arch. Vet. Sci. 7(2):15-26. <http://dx.doi.org/10.5380/ avs.v7i2.3977>

Edney A.T.B. \& Smith P.M. 1986. Study of obesity in dogs visiting veterinary practices in the United Kingdom. Vet. Rec. 118(14):391-396. <http://dx.doi.org/10.1136/vr.118.14.391><PMid:3716092>

Egenvall A., Bonnett B.N., Öhagen P., Olson P., Åke Hedhammar Â. \& von Euler H. 2005. Incidence of and survival after mammary tumors in a population of over 80,000 insured female dogs in Sweden from 1995 to 2002. Prev. Vet. Med. 69(1/2):109-127. <http://dx.doi.org/10.1016/j. prevetmed.2005.01.014><PMid:15899300>

Estrela-Lima A., Araújo M.S.S., Costa-Neto J.M., Teixeira-Carvalho A., BarrouinMelo S.M., Cardoso S.V., Martins-Filho O.A., Serakides R. \& Cassali G.D. 2010. Immunophenotypic features of tumor infiltrating lymphocytes from mammary carcinomas in female dogs associated with prognostic factors and survival rates. BMC Cancer 10:256. <http://dx.doi.org/10.1186/14712407-10-256><PMid:20525350>

Feitosa F.L.F. 2014. Semiologia Veterinária: a arte do diagnóstico. 3aㅡ ed. Roca, São Paulo. 627p.

Filho J.C.O., Kommers G.D., Masuda E.K., Marques B.M.F.P.P., Fighera R.A., Irigoyen L.F. \& Barros C.S.L. 2010. Estudo retrospectivo de 1647 tumores mamários em cães. Braz. J. Vet. Res. 30(2):177-185. <http://dx.doi.org/10.1590/S0100-736X2010000200014>

Fonseca C.S. \& Daleck C.R. 2000. Neoplasias mamárias em cadelas: influência hormonal e efeitos da ovario-histerectomia como terapia adjuvante. Ciência Rural 30(4):731-735. <http://dx.doi.org/10.1590/S0103$84782000000400030>$

Guerra M.R., Moura Gallo C.V. \& Mendonça G.A.S. 2005. Risco de câncer no Brasil: tendências e estudos epidemiológicos mais recentes. Revta Bras. Cancerol. 51(3):227-234.

Hellmén E. 2005. Complex mammary tumors in the female dog: a review. J. Dairy Res. 72(Suppl.1):90-97. <http://dx.doi.org/10.1017/s002202990500124x> <PMid:16180726>Hellmén E., Bergstrom R., Holmberg L., Spångberg I.B., Hansson K. \& Lindgren A. 1993. Prognostic factors in canine mammary tumors: A multivariate study of 202 consecutive cases. Vet. Pathol. 30(1):2027.<http://dx.doi.org/10.1177/030098589303000103><PMid:8442324>

Humphrey L.L., Helfand M., Chan B.K.S. \& Woolf S.H. 2002. Breast cancer screening: a summary of the evidence for the U.S. Preventive Services Task Force. Intern. Med. 137(5 Part 1):347-360. <http://dx.doi.org/10.7326/00034819-137-5_part_1-200209030-00012><PMid:12204020>

INCA 2016. Outubro Rosa 2016. Available at <http://www.inca.gov.br/ outubro-rosa/> Accessed on Dec. 10, 2017.

Kristiansen V.M., Nedtvedt A., Breen A.M., Langeland M., Teige J., Goldschmidt M., Jonasdottir T.J., Grotmol T. \& Sorenmo K. 2013. Effect of ovariohysterectomy at the time of tumor removal in dogs witg benign mammary tumors and hyperplastic lesions: a randomized controlled clinical trial. J. Vet. Int. Med. 27(4):935-942.<http://dx.doi.org/10.1111/jvim.12110><PMid:23701181>

Kristiansen V.M., Peña L., Díez Córdova L., Illera J.C., Skjerve E., Breen A.M., Cofone M.A., Langeland M., Teige J., Goldschmidt M. \& Sorenmo K.U. 2016. Effect of ovariohysterectomy at the time of tumor removal in dogs with mammary carcinomas: a randomized controlled trial. J. Vet. Intern. Med. 30(1):230-241. <http://dx.doi.org/10.1111/jvim.13812><PMid:26687731>
Kumaraguruparan R., Karunagaran R., Balachandran C., Manoar B.M. \& Nagini S. 2006. Of humans and canines: a comparative evaluation of heat shock and apoptosis-associated proteins in mammary tumors. Clin. Chim. Acta 365(1/2):168-176. <http://dx.doi.org/10.1016/j.cca.2005.08.018> <PMid:16176813>

Misdorp W. 2002. Tumors of the mammary gland, p.575-606. In: Meuten D. J. (Ed.), Tumors in Domestic Animals. 4th ed. Iowa State Press, Ames. Oliveira L.O., Oliveira R.T., Loretti A.P., Rodrigues R. \& Driemeier D. 2003. Aspectos epidemiológicos da neoplasia mamária canina. Acta Scient. Vet. 31(2):105-110.

Owen L.N. 1980. TNM Classification of Tumors in Domestic Animals. Geneva, World Health Organization. 53p.

Pascoli A.L., Negrão S.L., Oliveira L.E., Ferreira M.G.P.A., Filho N.P.R. \& De Nardi A.B. 2017. Campanha de orientação, prevenção e diagnóstico precoce de tumores mamários em cadelas e prevalência desses tumores diagnosticados durante a campanha realizada no município de Blumenau-SC. Arch. Vet. Sci. 22(2):66-00. <http://dx.doi.org/10.5380/avs.v22i2.48223>

Pérez Alenza D., Rutteman G.R., Peña L., Beyney A.C. \& Cuesta P. 1998. Relation between habitual diet and canine mammary tumors in a case-control study. J. Vet. Intern. Med. 12(3):132-139. <http://dx.doi.org/10.1111/j.1939-1676.1998.tb02108.x><PMid:9595373>

Queiroga F. \& Lopes C. 2002. Tumores mamários caninos, pesquisa de novos fatores de prognósticos. Revta Bras. Ciênc. Vet. 97(543):119-127.

Rutteman G.R., Withrow S.J. \& Macewen E.G. 2001. Tumors of the mammary gland, p.455-477. In: Withrow S.J. \& Macewen E.G. (Eds), Small Animal Clinical Oncology. 3rd ed. W.B. Saunders, Philadelphia.

Silva A.E., Serakides R. \& Cassali G.D. 2004. Carcinogênese hormonal e neoplasias hormônio-dependentes. Ciência Rural 34(2):625-633. <http://dx.doi.org/10.1590/S0103-84782004000200048>

Sonnenschein E.G., Glickman L.T., Goldschmidt M.H. \& Mckee L.J. 1991. Body conformation, diet, and risk of breast cancer in pet dogs: a case-control study. Am. J. Epidemiol. 133(7):694-703. <http://dx.doi.org/10.1093/ oxfordjournals.aje.a115944><PMid:2018024>

Sorenmo K.U. 2003. Canine mammary gland tumors. Vet. Clin. N. Am., Small Anim. Pract. 33(3):573-596. <http://dx.doi.org/10.1016/s01955616(03)00020-2><PMid:12852237>

Sorenmo K.U., Kristiansen V.M., Cofone M.A., Shofer F.S., Breen A.M., Langeland M., Mongil C.M., Grondahl A.M., Teige J. \& Goldschmidt M.H. 2009. Canine mammary gland tumors; a histological continuum from benign to malignant; clinical and histopathological evidence. Vet. Comp. Oncol. 7(3):162-172. <http://dx.doi.org/10.1111/j.1476-5829.2009.00184.x><PMid:19691645>

Sorenmo K.U., Shofer F.S. \& Goldschmidt M.H. 2000. Effect of spaying and timing of spaying on survival of dog with mammary carcinoma. J. Vet. Intern. Med. 14(3):266-270. <http://dx.doi.org/10.1892/0891-6640(2000)014<0266:eo sato $>2.3$. co; $2><$ PMid:10830539>

Sparano A.J., Wang M., Zhao F., Stearns V., Martino S., Ligibel A.J., Perez E.A., Saphner T., Wolff A.C., Sledge J.G.W., Wood W.C., Fetting J. \& Davidson N.E. 2012. Obesity at diagnosis is associated with inferior outcomes in hormone receptor-positive operable breast cancer. CA, Cancer J. Clin. 118(23):59375946. <http://dx.doi.org/10.1002/cncr.27527><PMid:22926690>

Stratmann N., Failing K., Richter A. \& Wehrend A. 2008. Mammary tumor recurrence in bitches after regional mastectomy. Vet. Surg. 37(1):82-86. <https://doi.org/10.1111/j.1532-950X.2007.00351.x><PMid:18199060>

Takalkar U.V., Asegaonkar S.B., Kulkarni U., Saraf M. \& Advani S. 2016. Clinicopathological profile of breast cancer patients at a Tertiary Care Hospital in Marathwada region of Western India. Asian Pac. J. Cancer Prev. 17(4):2195-2198. <http://dx.doi.org/10.7314/apjcp.2016.17.4.2195> <PMid:27221917>

Toríbio J.M.M.L., Lima A.E., Filho E.F.M., Ribeiro L.G.R., D’Assis M.J.M.H., Teixeira R.G., Damasceno K.A., Cassali G.D. \& Neto J.M.C. 2012. Caracterização clínica, diagnóstico histopatológico e distribuição geográfica das neoplasias 
mamárias em cadelas de Salvador, Bahia. Revta Ceres, Viçosa, 59(4):427433. <http://dx.doi.org/10.1590/S0034-737X2012000400001>

Widschwendter P., Friedl T.W.P., Schwentner L., DeGregorio N., Jaeger B., Schramm A., Bekes I., Deniz M., Lato K., Weissenbacher T., Kost B., Andergassen U., Jueckstock J., Neugebauer J., Trapp E., Fasching P.A., Beckmann M.W., Schneweiss A., Schrader I., Rack B., Janni W. \& Scholz C. 2015. The influence of obesity on survival in early, high-risk breast cancer: results from the randomized success a trial. Breast Cancer Res. 17(1):129. <http://dx.doi.org/10.1186/s13058-015-0639-3> <PMid:26385214>

Yoo K., Tajima K., Park S., Kang D., Kim S., Hirose K., Takeuchi T. \& Miura S. 2001. Postmenopausal obesity as a breast cancer risk factor according to estrogen and progesterone receptor status (Japan). Cancer Lett. 167(1):57-63. <http://dx.doi.org/10.1016/s0304-3835(01)00463-3> $<$ PMid:11323099> 